\title{
The Influence of Knowledge, Behaviour, Family Support and Paramedics' Role Towards Visual Acuity in After-Surgery Cataract Patients in General Hospitals in Kediri
}

\author{
Dyah Novi Wulansari, \\ Byba Melda Suhita, \\ Siti Farida \\ Indonesia \\ Email: \\ dyahnovi69@gmail.com
}

\begin{abstract}
Cataract remains the major cause of blindness in the world, it also has important role in visual disturbance both in developed countries and developing countries. There are factors contributing in the improvement of visual acuity or the result of cataract surgery, some of which are after-surgery care, family's ability to take care of the after-surgery patient, patient's knowledge, patient's behaviour, other underlying disease, and after-surgery complications.

The purpose of this research was to seek the most influencing factor towards after-surgery visual acuity. This research was a quantitative research model with analytical observational method, using cross sectional approach. There were 63 respondents consist of cataract patients who has done surgery in general hospitals in Kediri, chose by simple random sampling method. Data analysing technique was done by double linier statistic test. The result of this research using double linier regression test with 63 respondents gave significant value of 0.000 . This value was smaller than the $\mathrm{p}$ value $(0.05$ or $5 \%)$. This research analysis gave result in conclusion that there were significant effects of knowledge, respondents' behaviour, family support, and paramedics' role toward visual acuity in after-surgery cataract patients.
\end{abstract}

Keywords : Behaviour, Family support, Visual acuity aftersurgery

Received: March 12, 2019

Accepted : October 13, 2019

Published : November 26, 2019

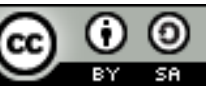

This is an open-acces article distributed under the terms of the Creative Commons Attribution-ShareAlike 4.0 International License. 


\section{INTRODUCTION}

Cataract is a disease that can be resulted from aging process, acquired since birth (congenital cataract), and also connected with traumatic process, both sharp trauma and blunt trauma, prolonged steroid use, or induced by other underlying disease such as diabetes or hypoparathyroidsm( Tamsuri,2010). The formation of cataract is marked by the accumulation of water inside the lens, the alteration of protein inside the lens, necrosis, and the alteration of normal balance of the lens fibers. The cloudiness inside the lens caused the transparent colour of the pupil changes colour into white or grey, which is usually found in various locations inside the lens such as cortex and nucleus(Ilyas,2010).

Of all fifty one percent(51\%) cases of blindness around the world, about twenty millions cases were caused by cataract. Cataract remains the major cause of blindness, cataract also has important role in decreasing visual acuity both in developed ccountry and developing country(WHO,2012) .

In Indonesia, the prevalence of cataract in 2013 is $1.8 \%$, while in East Java the prevalence of cataract is $1.6 \%$. According to the data that has been reported from medical services to Medical Department in Kediri, it is known that cataract was the most common ocular disease after other refractive disorder each year (Kemenkes RI,2013)..

Surgery was the only treatment for cataract that has purpose in correcting visual acuity of cataract patient. Cataract surgery was done by subtracting the cataract lens, followed by replacement and implantation with intraocular lens (IOL) (Sulakso KA,2008). About more than ninety percent of cataract surgeries succeed with the improvement of visual function which is presented by the improvement of visual acuity in after-surgery cataract patients. Most of the patients have achieved good category in visual acuity, which is ranged from 6/18 - 6/6 after four until eight weeks(Rahmadita,2008).

There are factors contributing in visual acuity improvement or the result of cataract surgery, some of them are after-surgery care, the ability of the family to take care of the after-surgery patient, patient's knowledge, patient's behaviour, other underlying disease and also after-surgery complications.

This research had purpose to seek the influence of patient's knowledge, patient's behaviour, family support and paramedics' role towards visual acuity in after-surgery cataract patients, and also to know the most contributing factor that played role in improving visual acuity of after-surgery cataract patients in general hospitals in Kediri.

\section{MATERIALS AND METHODS}

This research was a quantitative research model with analytical observational method, using cross sectional approach. Data was collected using questionnaires from 63 respondents, who are consist of cataract patients that has done surgery in Muhammadiyah Ahmad Dahlan Hospital Kediri, Aura Syifa Hospital, and DahaHusada General Hospital Kediri. The independent variables of this research were knowledge, behaviour, family support and paramedics' role, while the independent variables of this research were post cataract surgery's visual acuity. The respondents chose by simple random sampling method. Data was then analysed using double linier statistic test.

\section{RESULT}

Respondents' Characteristics Distribution

Table 1. Respondents' Characteristics Based on Age

\begin{tabular}{|c|c|c|c|c|c|}
\hline & & $\begin{array}{c}\text { Frequenc } \\
y\end{array}$ & Percent & $\begin{array}{l}\text { Valid } \\
\text { Percent }\end{array}$ & $\begin{array}{c}\text { CumulativePerc } \\
\text { ent }\end{array}$ \\
\hline \multirow[t]{5}{*}{ Valid } & $\begin{array}{l}36-45 \\
\text { years }\end{array}$ & 3 & 4,8 & 4,8 & 4,8 \\
\hline & $\begin{array}{l}46-55 \\
\text { years }\end{array}$ & 17 & 27,0 & 27,0 & 31,7 \\
\hline & $\begin{array}{l}56-65 \\
\text { years }\end{array}$ & 23 & 36,5 & 36,5 & 68,3 \\
\hline & $>65$ years & 20 & 31,7 & 31,7 & 100,0 \\
\hline & Total & 63 & 100,0 & 100,0 & \\
\hline
\end{tabular}

From 63 respondents, it is known that 23 respondents (36.5\%) were on age 56 to 65 years old. 
Table 2. Respondents' Characteristics Based on Sex

\begin{tabular}{llrrrr}
\hline & & \multicolumn{2}{c}{ Frequenc } & & Valid \\
y & Percent & Percent & $\begin{array}{r}\text { CumulativePerc } \\
\text { ent }\end{array}$ \\
\hline Valid & Male & 27 & 42,9 & 42,9 & 42,9 \\
\cline { 2 - 7 } & Female & 36 & 57,1 & 57,1 & 100,0 \\
\cline { 2 - 7 } & Total & 63 & 100,0 & 100,0 &
\end{tabular}

From 63 respondents, it is known that 36 respondents were female $(57,1 \%)$.

Table 3. Respondents' Characteristics Based on Marital Status

\begin{tabular}{llrrrrr}
\hline \multirow{2}{*}{ Valid } & & & \multicolumn{2}{c}{ Valid } & \multicolumn{2}{c}{ CumulativePerc } \\
Single & Frequency & Percent & Percent & ent \\
\cline { 2 - 6 } & Married & 4 & 6,3 & 6,3 & 6,3 \\
\cline { 2 - 6 } & Widow & 13 & 71,4 & 71,4 & 77,8 \\
\cline { 2 - 6 } & Widower & 1 & 1,6 & 1,6 & 100,0 \\
\cline { 2 - 6 } & Total & 63 & 100,0 & 100,0 & \\
\hline
\end{tabular}

Based on information in table 3 above, most of the respondents were married, with the total 45 out of $63(71.4 \%)$.

Table 4. Respondents' Characteristics Based on Education

\begin{tabular}{|c|c|c|c|c|c|}
\hline & & \multicolumn{2}{|l|}{ Frequenc } & \multirow{2}{*}{$\begin{array}{c}\text { Valid } \\
\text { Percent }\end{array}$} & \multirow{2}{*}{$\begin{array}{c}\text { CumulativePerc } \\
\text { ent }\end{array}$} \\
\hline & & $\mathrm{y}$ & Percent & & \\
\hline \multirow[t]{5}{*}{ Valid } & $\begin{array}{l}\text { Elementary } \\
\text { School }\end{array}$ & 16 & 25,4 & 25,4 & 25,4 \\
\hline & $\begin{array}{l}\text { Junior High } \\
\text { School }\end{array}$ & 9 & 14,3 & 14,3 & 39,7 \\
\hline & High School & 26 & 41,3 & 41,3 & 81,0 \\
\hline & $\begin{array}{l}\text { Diploma/Bache } \\
\text { lor }\end{array}$ & 12 & 19,0 & 19,0 & 100,0 \\
\hline & Total & 63 & 100,0 & 100,0 & \\
\hline
\end{tabular}

Based on table 4, respondents' latest education was mostly high school, with the total 26 respondents $(41.3 \%)$.

Table 5. Respondents' Characteristics Based on Job

\begin{tabular}{|c|c|c|c|c|c|}
\hline & & $\begin{array}{c}\text { Frequenc } \\
\mathrm{y}\end{array}$ & $\begin{array}{c}\text { Percen } \\
\mathrm{t}\end{array}$ & $\begin{array}{l}\text { Valid } \\
\text { Percent }\end{array}$ & $\begin{array}{c}\text { CumulativePerc } \\
\text { ent }\end{array}$ \\
\hline \multirow[t]{5}{*}{ Valid } & Farmer & 9 & 14,3 & 14,3 & 14,3 \\
\hline & $\begin{array}{l}\text { Government's } \\
\text { employee }\end{array}$ & 8 & 12,7 & 12,7 & 27,0 \\
\hline & $\begin{array}{l}\text { Private } \\
\text { employee }\end{array}$ & 18 & 28,6 & 28,6 & 55,6 \\
\hline & Other & 28 & 44,4 & 44,4 & 100,0 \\
\hline & Total & 63 & 100,0 & 100,0 & \\
\hline
\end{tabular}

Based on table 5, respondents with job other than farmer,government's and private employee were 28 respondents $(44.4 \%)$. 
Variable's Characteristics Distribution

Table 6. Frequency Distribution of Respondents' Education

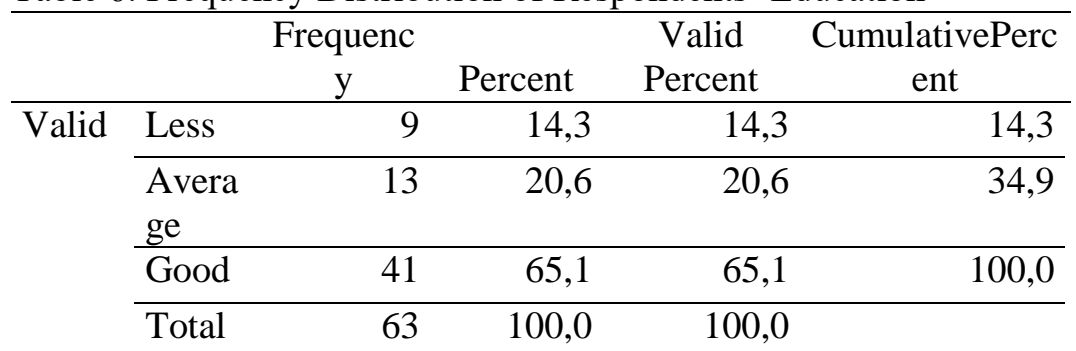

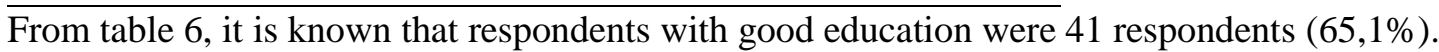

Table 7. Frequency Distribution of Respondents' Behaviour

\begin{tabular}{|c|c|c|c|c|c|}
\hline & & $\begin{array}{c}\text { Frequenc } \\
y\end{array}$ & Percent & $\begin{array}{l}\text { Valid } \\
\text { Percent }\end{array}$ & $\begin{array}{c}\text { CumulativePerce } \\
\mathrm{nt}\end{array}$ \\
\hline \multirow[t]{4}{*}{ Valid } & Less & 9 & 14,3 & 14,3 & 14,3 \\
\hline & $\begin{array}{l}\text { Averag } \\
\mathrm{e}\end{array}$ & 47 & 74,6 & 74,6 & 88,9 \\
\hline & Good & 7 & 11,1 & 11,1 & 100,0 \\
\hline & Total & 63 & 100,0 & 100,0 & \\
\hline
\end{tabular}

$\overline{\text { From table 7, the result of frequency distribution analysis of respondents' }}$ behaviour showed that about 47 respondents have average behaviour $(74.6 \%)$.

Table 8. Frequency Distribution Based on Family Support

\begin{tabular}{|c|c|c|c|c|c|}
\hline & & $\begin{array}{c}\text { Frequenc } \\
y\end{array}$ & Percent & $\begin{array}{l}\text { Valid } \\
\text { Percent }\end{array}$ & $\begin{array}{c}\text { CumulativePerce } \\
\text { nt }\end{array}$ \\
\hline \multirow{4}{*}{$\begin{array}{l}\text { Vali } \\
\text { d }\end{array}$} & Less & 1 & 1,6 & 1,6 & 1,6 \\
\hline & $\begin{array}{l}\text { Averag } \\
\mathrm{e}\end{array}$ & 15 & 23,8 & 23,8 & 25,4 \\
\hline & Good & 47 & 74,6 & 74,6 & 100,0 \\
\hline & Total & 63 & 100,0 & 100,0 & \\
\hline
\end{tabular}

Table 8 showed that 47 respondents (74.6\%) have good family support.

Table 9. Frequency Distribution of Paramedics' Role

\begin{tabular}{llrrrrr}
\hline & & & & Valid & CumulativePerce \\
Valid & Avera & 19 & 30,2 & 30,2 & nt \\
& \begin{tabular}{l} 
ge \\
\cline { 2 - 6 }
\end{tabular} & Good & 44 & 69,8 & 69,8 & 30,2 \\
\cline { 2 - 6 } & Total & 63 & 100,0 & 100,0 & & 100,0 \\
\hline
\end{tabular}

From table 9, respondents who explained that paramedics have good role based on their aftersurgery experience are 44 respondents $(69,8 \%)$.

Table 10. Frequency Distribution of Visual Acuity

\begin{tabular}{|c|c|c|c|c|c|}
\hline & & $\begin{array}{c}\text { Frequenc } \\
\mathrm{y}\end{array}$ & Percent & $\begin{array}{l}\text { Valid } \\
\text { Percent }\end{array}$ & $\begin{array}{c}\text { CumulativePerc } \\
\text { ent }\end{array}$ \\
\hline \multirow[t]{4}{*}{ Valid } & Less & 6 & 9,5 & 9,5 & 9,5 \\
\hline & $\begin{array}{l}\text { Averag } \\
\text { e }\end{array}$ & 9 & 14,3 & 14,3 & 23,8 \\
\hline & Good & 48 & 76,2 & 76,2 & 100,0 \\
\hline & Total & 63 & 100,0 & 100,0 & \\
\hline
\end{tabular}


Table 10 showed frequency distribution analysis of respondents' visual acuity after cataract surgery. Respondents who have good visual acuity were 48 out of 63 (76,2\%).

Simultaneous Double Linier Regression Test

Table 11. Simultaneous double linier regression test

\begin{tabular}{llrrrrl}
\hline Model & & Sum ofSquares & df & MeanSquare & F & Sig. \\
\hline 1 & $\begin{array}{l}\text { Regressio } \\
\mathrm{n}\end{array}$ & 14017,400 & 4 & 3504,350 & 5,797 &, $000^{\mathrm{b}}$ \\
\cline { 2 - 7 } & & & & & & \\
\cline { 2 - 7 } & Residual & 35060,891 & 58 & 604,498 & & \\
\cline { 2 - 6 } & Total & 49078,291 & 62 & & & \\
\hline
\end{tabular}

a. DependentVariable: Visus

b. Predictors: (Constant), Peranan, Perilaku, Pengetahuan, Dukungan_Keluarga

Table 11 gave information of significance value of 0.000 . This value was smaller than $p$ value $(0.05)$, thus the conclusion that can be made is there was a significant influence of education, respondents' behaviour, family support, and paramedics' role towards respondents' visual acuity.

\section{DISCUSSION \\ Influence of Education towards Visual Acuity in After-Surgery Cataract Patients in General Hospitals in Kediri}

This research shows that from 63 respondents, there were 37 person (58.7\%) who are well educated have good visual acuity, while 1 person who is less educated had less visual acuity $(1.6 \%)$. The result of partial parameter statistic test gave significant value of 0.509 which is larger than 0.05 , it means that there is no direct influence of education towards after-surgery's visual acuity ( $p$ value $<$ 0,05). According to Notoatmodjo (2010), education or cognitive is a vital component in shaping someone's action. Education level in cognitive domain has six levels starts with "know", means remembering the lessons that have been learned before. This process was then continued with "understanding" or "comprehension", which means the ability to explain well about known object and interpret lesson well. These two levels were then continued with higher processes: application, analysis, synthesis, and evaluation.

Knowledge was influenced by many factors (Meliono, 2009), some of them are education, media, experience, information's exposure, and the environment.

From the research that has been done by Novita Malowring (2014) towards 63 respondents in Public Eye Clinic in Northern Sulawesi, based on chi square test the result of the significant value was 0.00 , less than $p$ value (0.05). It can be concluded that there was a significant relationship between knowledge and after-cataract-surgery care obedience.

On the other side, the after-surgery cataract patients who became respondents in this research explained that they received information about cataract and its symptoms from various sources, for the example direct education from paramedics and other information received from family, relatives, colleagues, or from health posters and medical services' publication. Patients also received information from doctors and paramedics, especially when they consult the symptoms they felt that may lead the diagnosis to cataract.

The submission of health information sometimes cannot be fully received by the patients. Language difference remains the major problem. An effort that can be made to avoid missing information in doctor-patient relationship is enabling a mediator who could understand doctor's explanation and be able torelay the information with the language that patient can understand.

In this study, from the education level of respondents $41.3 \%$, most of the number of respondents in high school education, so that knowledge of cataracts, causes, treatment and success of cataract surgery which is influenced by care and behavior of postoperative patients of respondents is less known. The higher the level of education, especially those who have a health education background, will know more about cataracts, so that the success rate of surgery in this case the improvement of vision will certainly be better than the respondents who were educated outside the health department. 


\section{Influence of Healthy Behaviour towards Visual Acuity in After-Surgery Cataract Patients in General Hospitals in Kediri}

The results of this research showed that of all 63 respondents, 37 people (58.7\%) who had average healthy behaviour have good visual acuity, while 3 people who had less healthy behaviour have less visual acuity (4.8\%). Partial parameter statistic test gave significant value of 0.03 , showed that there is significant influence from healthy behaviour towards after-surgery's visual $(\operatorname{sig}<0.05)$.

Application is the third knowledge level after "know" and understand. Application is meant by the ability to utilise the lessons that has been learned before in the real situation or condition, for the example the utilisation of law, formula, methods, principle, in other context or situation, in this condition it could be meant by patients' healthy behaviour. The healthy behaviour itself can be classified into three groups consist of health maintenance, the utilization of health facilities, and environmental health (Notoatmodjo, 2010).

Previous research has been done by Siswoyo (2016) titled the effect of psychoeducation towards knowledge, intensity, and role behaviour of cataract patients with Ajzen's theory of planned behaviour approach. This research used quasi experimental design pre and post test control group, with simple random sampling method. The result of this research was as follows: 1) there is significant influence of psychoeducation towards cataract patients' knowledge; 2) there is significant influence of psychoeducation towards cataract patients' intention; 3) there is significant influence of psychoeducation towards cataract patients' role.

As explained above, behavior is very influential on the success or improvement of postoperative vision, for this reason the patient should take actions or supportive behaviors, namely getting used to drinking at least 8 glasses of water per day, consuming foods high in fiber, vegetables and fruit which can later produce faeces soft, so patients do not need to push during bowel movements. In male patients should not smoke postoperatively, so also housewives also do not cook themselves, because the smoke produced will hit the eyes causing irritation, so that it will interfere with the postoperative wound healing process. The use of glasses must be done at any time except during sleep and bathing, so that the eyes avoid dust, wind or other foreign objects that can cause postoperative complications. The patient's health behaviors are based on what he knows and experiences that the patient knows, both his own experience and the experiences of others, especially close relatives.

Respondents who have health behaviors can not be caused by a variety of things, both in terms of lack of health education, no good experience in treating injuries, poor personal and environmental hygiene, and insufficient resources to gain access to hygiene and poor health. The relationship between health behavior and patient vision shows that how patients manage their lifestyles, how to behave well, and how patients carry out postoperative care more or less will affect the patient's health, which in this condition is a sharp condition for patients after cataract surgery.

\section{Influence of Family Support towards Visual Acuity in After-Surgery Cataract Patients in General Hospitals in Kediri}

The results of this research showed that from 63 respondents, there are 36 people (57.1\%) who claimed that they had good family support and good visual acuity, while 1 person (1.6\%) had average family support and average visual acuity. Partial parameter statistic test gave significant value if 0.046 , meant that there is significant influence of family support towards after-surgery's visual acuity (sig< $0.05)$.

According to Friedman, Bowden, \& Jones (2010), in order to achieve the objective of family health nursing care, the family has task to maintain its members' good health and take care of each other,some of them could be having awareness in each member's health development disorder, make a decision for doing the right thing, giving good care to a family member who suffered from disease and cannot take care of themselves due to their age or handicapped, maintain the condition inside the house which benefits family members' health and personality development, also maintain the relationship between family and health facilities.

Previous research gave significant value of 0.00 , means there was significant relationship between family support and patients' obedience to do after-surgery control in cataract patients in Eye Policlinic Dr. H. Moch. Ansari Saleh General Hospital Banjarmasin in 2017 with strong inter variable relationship. 
Another research that has been done in the area of JelbukJember Community Health Centre by Ahmad Afif Wijaya (2015) using spearman rank correlation statistic test gave significant value of 0.002 , means there is significant relationship between knowledge and family's ability to do after-surgery care in cataract patients.

In this research, there is significant influence of family support towards after-surgery's visual acuity. This result may be reasoned by various factors such as incomplete family, long distance between each family members, or inadequate communication between family members that may cause low support from family due to the fact of each other's unknown condition, having low information about cataract that may lead to inadequate care. Patients usually seek information themselves or consult with the doctors or paramedics in order to avoid false care. Good family support is the result of good family communication. Family problem solving and family attention are the basis to achieve family support mainly in patients' health after cataract surgery.

Good family support is obtained by paying attention to how to treat post cataract surgery wounds by giving the drug appropriately according to the rules, family members help fulfill the life needs of post cataract surgery patients because their activities or activities are limited, deliver and remind patients when they need postoperative control. With family support, the success of cataract surgery that can be seen from postoperative visual progress will be successful.

\section{Influence of Paramedics' Role towards Visual Acuity in After-Surgery Cataract Patients in General Hospitals in Kediri}

The result of this research shows that from 63 respondents there are 40 people $(63.5 \%)$ who explained that they experienced good paramedics' role and have good visual acuity, while 3 people who explained that they experienced average paramedics' role and have less visual acuity (4.8\%). Partial parameter statistic test gave significant value of 0.835 , means that there is no significant influence of paramedics' role towards after-surgery's visual acuity $($ sig $<0,05)$.

Along the after-surgery period the nursing process is intended to stabilize the patients' physiological equilibrium, reduce and avoid pain. Assessment and intervention help patients to return their optimal function fast, safely, and comfortably (Potter \& Perry, 2008). Paramedics have important role in improving awareness, intention, and the ability to live healthy mainly for after-cataract-surgery patients through their role as communicator, motivator, facilitator, and counsellor.

As a communicator, paramedics gave information clearly to the patients to improve the education and correct the wrong behaviour towards health and disease(Notoatmodjo, 2010).

Previous research that has been done by Alberth Darmono Sarimin, MD (2016) with chi square analysis for bivariate and logistic regression for multivariate. Bivariate analysis showed that all independent variables are related to dependent variables with each $p$ value: Cataract emergency ( $p$ value $=0.001$ ), Communicator's empathy ( $\mathrm{p}$ value $=0.035$ ), Information about cataract that can be received ( $\mathrm{p}$ value $=$ $0.001)$, Feedback that has been done by communicator about cataract ( $p$ value $=0.002$ ). From multivariate analysis it can be concluded that the most influencing variable in medical information clarity is the information about cataract that can be received, while the other has no significant influence. Communicators who have low ability to give information which the patients can receive have risk 28 times larger than the communicator who have high ability to give information which the patients can receive. There are also control variable along the lines of age, education level, and respondents' class treatment also have influence.

Paramedics should evaluate patients' comprehension about information received, and also give message to the patient whenever the unwanted side effect occurs they should come directly to health facility and report it to the paramedics (Mandriwati, 2008). A paramedic should also be able to give motivation, direction, and guidance to support and make the patient realize their condition so that they will be aware of their problem, and could develop their potential to solve the problem and give opportunities if the patient wants to consult in private(Sardiman, 2009; Novita, 2011).

Paramedics also have role as counsellor in their relationship with patients through showing empathy and teach the patients by experience, can accept the patient the way they are, hear the consultation patiently, optimists, could accept different thoughts, do not judge, be able to keep the secret, support decision making, give support, build support based on trust, could communicate, understand patients' feeling and anxiety, also patients' boundaries(Simatupang,2009). 
Roles and the intervention of paramedics have influence towards visual acuity improvement in the light fact of advice, education, and training that the paramedics gave, patients' knowledge about cataract will improve and they could train themselves to keep healthy behaviour and draw more attention to aftersurgery care which later will have effect to visual acuity.

The intensity of paramedics' role towards patients can be affected by many factors, for the example the frequency of patients' health visit, the meeting time between paramedics and patients, also the paramedics' act to do home visit for cataract patients.

From the above reality, researchers assume that the role and intervention of health workers has an influence on improving the vision of patients after cataract surgery, because through advice, education, and training provided by health workers, patient knowledge about cataracts will increase and patients can train themselves to behave well and pay more attention to postoperative care which will affect the visual repair a bit more. Providing information by health personnel needs to be done before and after the patient has had surgery, giving this information is also given when the patient is accompanied by the patient's family.

Health workers need to notify activities that patients can and cannot do after surgery, when to control, how to administer drugs, and what symptoms or symptoms the patient feels must be conveyed to the doctor so that postoperative complications do not occur.

From the description above, the researcher argues that the success of cataract surgery that can be seen with the progress of vision or the ability of the lens to see an object after an operation is strongly supported by good family behavior and support.

\section{Influence of Knowledge, Health Behaviour, Family Support and Paramedics' Role towards Visual Acuity in After-Surgery Cataract Patients in General Hospitals in Kediri}

This research's result shows that from 63 respondents with double linier statistic test gave significant value of 0.001 . This value was smaller than $p$ value $(0.05)$, thus the conclusion that can be made was there is significant influence of knowledge, respondents' behaviour, family support, and paramedics' role towards patients' visual acuity.

Visual acuity is defined by the ability to read standardized pattern test from determined distance. Generally, the result of the test will be compared with normal sight. Some factors such as lighting, contrast, various colour test, exposure time, and refraction disorder will alter visual acuity (Ilyas, 2015).

Visual acuity criteria according to WHO was divided into as follow: good visual acuity (6/6 to 6/18) equals 85\%; average visual acuity (less than 6/18 to 6/60) equals less than $15 \%$ to $5 \%$; low visual acuity (less than 6/60) equals less than 5\%. In Vision 2020 - The Right to Sight, WHO targeted good surgery quality will be achieved as long as the best correction reach $6 / 18$ at least $85 \%$.

Previous research that has been done by Anny Sulistiyowati (2011) in Kendal Hospital and Bhayangkara Policlinic Semarang Central Java, it is concluded that the stability of visual acuity after cataract surgery remains stable 8 weeks after the surgery. Patients' age has no effect in the visual acuity after surgery in senile cataract. Visual acuity in senile cataract patient can be improved by surgery and using glasses after the surgery.

Previous research in Eye Policlinic Arifin Achmad General Hospital Pekanbaru in 2015, there were some factors influencing patient's healing such as age, nutrition, and lifestyle.

From statistics test that was used to search the significant result of the independent variable partially or individually, it is known that the variables which have significant roles individually are behaviour and family support. This conclusion based on significant value that resulted from those two variables with the value of 0.000 and 0.036 , which are smaller than $0.05(5 \%)$.

Low visual acuity in cataract patients may be caused by various factors, one of them is inadequate after-surgery care. Cataract patients who are already undergo surgery have risk of suffering endophthalmitis or other intra ocular inflammation due to history of invasive procedure, thus hygienic and good after-surgery care is needed to avoid reappearance of cloudy lens mainly because of infection and inflammation.

From the explanation above the researcher gave opinion that cataract surgery's success that can be observed is the improvement of visual acuity or the lens ability to see object, which also needs to be supported by good behaviour and family support. 
The behavior that supports the success of cataract surgery certainly needs to be recognized by patients before the operation, so that after performing surgery the patient can perform healthy behaviors such as always wearing glasses, consuming foods that can make the stool soft so that the patient does not need to push during bowel movements. For everyday life needs to be supported by family support.

Family support also influences the success of cataract surgery, for that it needs family support to patients both directly by delivering control, caring for wounds, giving eye drops according to the rules, meeting the life needs of patients during the recovery period, and indirectly by reminding patients of activities which may or may not be done after cataract surgery.

With healthy behavior and good family support for post cataract surgery patients, the success rate of cataract surgery seen with improved vision can be achieved.

\section{CONCLUSION}

The conclusion drawn from this research is there was an influence of knowledge, behaviour, family support, and paramedics' role towards visual acuity in after-surgery cataract patients in General Hospitals in Kediri, with patients' behaviour as the most dominant factor.

\section{REFERENCES}

American Academi of Ophtalmologi. 2011, Lens of Cataract. Section II, Basic and Clinical Science Course, Singapore, pp 166- 203

Departemen Kesehatan RI. Ditjen Bina Kesehatan Masyarakat. 2008, Direktorat Bina Upaya Kesehatan Puskesmas.

Departemen Kesehatan RI. Ditjen Bina Kesehatan Masyarakat. Hasil survei Kesehatan Indonesia Penglihatan dan Pendengaran 2008, Jakarta

Dinkes Kota Kediri, 2017, Laporan Penyakit Mata Kediri 2017., Seksi Yankes, Kediri

Friedman, MM, Bowden, O \& Jones, M. 2010. Buku Ajar keperawatan Keluarga: riset, teori, \& praktik ; alih bahasa, Achir Yani S. Hamid...(et al.); editor edisi bahasa Indonesia, Estu Tiar, Ed.5, EGC, Jakarta

Ilyas, Sidarta. 2008, Katarak Lensa Mata Keruh, Edisi 4, Balai Pustaka FKUI, Jakarta, pp 64

Ilyas, Sidarta. 2015, Ilmu Penyakit Mata, FK UI Press, Jakarta

Ilyas, Sidarta, Maylangkai, H. B., Taim, Hilman., Salman, R. Raman., Simarmata, Monang., Widodo, S. Widodo, 2010, Ilmu Penyakit Mata Untuk Dokter Umum dan Mahasiswa Kedokteran, Sagung Seto Press, Jakarta

Keputusan Menteri Kesehatan Republik Indonesia Nomor. 1473/MENKES/SK/X/2014, tentang Rencana Strategi Nasional Penanggulangan Gangguan Penglihatan Dan Kebutaan Untuk Mencapai Vision 2020,p 2-6

Maloring, Novita. 2014, Hubungan pengetahuan dan sikap dengan kepatuhan perawatan pada pasien post operasi katarak di balai kesehatan mata masyarakat Sulawesi Utara diakses dari http://ejournal.unsrat.ac.id/index.php/jkp/article/view/5252

Mandriwati ,2008, Penuntun Belajar Asuhan Kebidanan Ibu Hamil, ECG, Jakarta

Meliono, Irmayanti, 2011, editors, Pengetahuan, Lembaga Penerbit FEUI, Jakarta

Notoatmodjo. 2012, Metodologi Penelitian Kesehatan. Jakarta: Rineka Cipta

Notoadmodjo. 2010, Promosi Kesehatan dan Ilmu Perilaku. Jakarta : Rineka Cipta 
Novita. 2011, Promosi Kesehatan Dalam Pelayanan Kebidanan, Salemba Medika, Jakarta

Novitamaloring. 2014, Hubungan Pengetahuan dan Sikap Dengan Kepatuhan Perawatan pada Pasien Post Operasi Katarak

Potter PG, Perry AG. 2008. Buku Ajar Fundamental Keperawatan: Konsep, Proses, dan Praktik, Volume 2. , EGC, Jakarta

Sardiman, A.M. 2009, Interaksi dan Motivasi Belajar Mengajar, Rajawali Pers, Jakarta

Simatupang. 2009, Manajemen Pelayanan Kebidanan, EGC, Jakarta

Tamsuri, Anas. 2010, Gangguan Mata \& Penglihatan ; Keperawatan Medikal Bedah, Editor Egi Komara Yudha., EGC, Jakarta

World Health Organization (WHO). 2014, Priority Eye Disease. http://www.who.int/blindness/causes/priority/en/index1,html.

bstetrics Theory. Jakarta: EGC zi-dengan-lila.html?m=1 